\title{
PENGEMBANGAN AGROWISATA BERLANDASKAN KONSEP TRI HITA KARANA DI SUBAK UMA LAMBING, KECAMATAN ABIANSEMAL, KABUPATEN BADUNG
}

\author{
Agrotourism Development Based On The Concept Of Tri Hita Karana In \\ Subak Uma Lambing Abiansemal Sub-District Of Badung Regency
}

\author{
Ni Luh Putu Erma Mertaningrum, Wayan Windia, \\ Ratna Komala Dewi
}

Program Studi Magister Agribisnis, Fakultas Pertanian, Universitas Udayana, Bali, Indonesia

Email: ermamertaningrum@gmail.com

\begin{abstract}
In an effort to agro-tourism development at Subak Uma Lambing, it is necessary to analyze the potential, form of development, and suitability between the ideal situation and the actual situation of subak. Based on that, it is necessary to do analysis based on the concept of Tri Hita Karana. The purpose of this study is to analyze the potential, the form of agro-tourism development, and the suitability between the ideal situation and the actual situation at Subak Uma Lambing related to the agro-tourism development based on Tri Hita Karana concept. This research used pekaseh and tourism actors as a main informant, and the member of subak as respondent. Methods and techniques of data collection used are observation, in-depth interviews, questionaires, documentation, and triangulation. Data analysis methods and techniques used are qualitative descriptive analysis, and matrices analysis of relationships between technology subsystems and cultural sub-systems. The results showed that Subak Uma Lambing has the potential of tourist attraction, transportation type, electricity flow and lighting. Roads, parking lots, health facilities, food and beverage kiosks, souvenir shops, lodging, and accessibility based on distance and ease with other tourist locations. Agro-tourism is developed using an mindset aspect, social aspect, and artifacts aspect with alternative forms of agro-tourism is tracking, jogging, cycling, metekap, nandur, manyi, feeding cows, feeding fish, fishing trips, fruits and vegetables picking tours, studying rindic instruments, watching ritual activities, enjoy typical Balinese food, mejejahitan, capil wraping, traditional games, entertainment Balinese Dance and stay at krama subak home. In general, the application of the concept of Tri Hita Karana approaching the ideal situation, but on the relationship of social sub-system with sub-organoware system has not reached the ideal. In this study, it is advisable to maintain the cleanliness of irrigation channels, as well as to improve and equip facilities and infrastructure. An agreement needs to be made on manners, local government and tourism bureaus, collaboration between subak institution and krama to realizing the artifact aspects.
\end{abstract}

Keywords: Agrotourism Development, Agrotourism of Subak, Tri Hita Karana

\begin{abstract}
ABSTRAK
Dalam upaya pengembangan agrowisata di Subak Uma Lambing, perlu untuk menganalisis potensi, bentuk pembangunan, dan kesesuaian antara situasi ideal dan situasi aktual subak. Berdasarkan hal tersebut, maka perlu dilakukan analisis berdasarkan konsep Tri Hita Karana. Tujuan dari penelitian ini adalah untuk menganalisis potensi, bentuk pengembangan agrowisata, dan kesesuaian antara situasi ideal dan situasi aktual di Subak Uma Lambing terkait dengan pengembangan agrowisata berdasarkan konsep Tri Hita Karana. Penelitian ini menggunakan pekaseh dan pelaku pariwisata sebagai informan utama, dan anggota subak sebagai responden. Metode dan teknik pengumpulan data yang digunakan adalah observasi, wawancara mendalam, kuesioner, dokumentasi, dan triangulasi. Metode dan teknik analisis data yang digunakan adalah analisis deskriptif kualitatif, dan analisis matriks hubungan antara sub-sistem teknologi dan sub-sistem budaya. Hasil penelitian menunjukkan bahwa Subak Uma Lambing memiliki potensi objek wisata, jenis transportasi, aliran listrik dan penerangan. Jalan, tempat parkir, fasilitas kesehatan, kios makanan dan minuman, toko suvenir, penginapan, dan aksesibilitas berdasarkan jarak dan kemudahan dengan lokasi wisata lainnya. Agrowisata dikembangkan dengan menggunakan aspek pola pikir, aspek sosial, dan aspek artefak dengan bentuk-bentuk alternatif agrowisata adalah pelacakan, jogging, bersepeda, metekap, nandur, manyi, memberi makan sapi, memberi makan ikan, perjalanan memancing, memetik buah-buahan dan sayuran., mempelajari instrumen rindik, menonton kegiatan ritual, menikmati makanan khas Bali, mejejahitan, pembungkus capil, permainan tradisional, hiburan Tari Bali dan menginap di rumah krama subak. Secara umum penerapan konsep Tri Hita Karana mendekati situasi ideal, tetapi pada hubungan sub-sistem sosial dengan sistem sub-organoware belum mencapai yang ideal. Dalam studi ini, disarankan untuk menjaga kebersihan saluran irigasi, serta meningkatkan dan melengkapi fasilitas dan infrastruktur. Perlu dibuat kesepakatan tentang tata krama, pemerintah daerah dan biro pariwisata, kolaborasi antara lembaga subak dan krama untuk mewujudkan aspek artefak.
\end{abstract}




\section{PENDAHULUAN}

\section{Latar Belakang}

Subak merupakan suatu organisasi atau lembaga irigasi tradisional di Bali yang memiliki kewenangan untuk mengelola sistem pengairan pertanian. Bagi masyarakat Bali, subak bukan sekedar sistem irigasi, namun juga merupakan konsep kehidupan. Dimana dalam pandangan masyarakat Bali, subak merupakan manifestasi dari penerapan filosofi konsep Tri Hita Karana yang memiliki arti sebagai tiga penyebab terciptanya kebahagiaan dan kesejahteraan yang menjadi dasar dari setiap budaya atau kebiasaan agraris masyarakat Bali.

Dewasa ini kelestarian subak mulai terancam dikarenakan gencarnya program pembangunan di luar sektor pertanian termasuk pesatnya perkembangan pariwisata akibat dari berkembangnya globalisasi. Perkembangan globalisasi memberikan dampak yang dapat menjadi tantangan, peluang bahkan ancaman bagi keberadaan subak. Untuk menyikapi dampak tersebut, salah satu alternatif yang dapat dilakukan yaitu dengan mengembangkan bisnis dalam kawasan subak dengan cara mensinergikan sektor pertanian dan pariwisata.

Pusat dari pengembangan pariwisata di Provinsi Bali terletak di merupakan pusat pengembangan pariwisata di Bali. namun, pengembangan pariwisata selama ini hanya terfokus pada kawasan Badung Selatan, hal tersebut menyebabkan ketimpangan pembangunan antar wilayah. Padahal, kawasan lainnya juga memiliki potensi yang dapat dikembangkan salah satunya pada kawasan Badung Tengah. Berdasarkan dengan memanfaatkan potensi pertanian sebagai obyek wisata. Namun, agar terwujud suatu pengembangan agrowisata yang berkelanjutan maka diperlukan hubungan harmoni baik antara manusia dengan Tuhan, dengan sesama maupun dengan lingkungan sekitarnya. Hubungan harmoni tersebut dapat dijalin dengan mengembangkan agrowisata berlandaskan Konsep Tri Hita Karana.

Subak Uma Lambing merupakan salah satu subak yang berada Kawasan Badung Tengah tepatnya di kecamatan Abiansemal. Sebelumnya telah berkembang suatu wacana untuk melakukan pengembangan agrowisata pada subak ini. Berdasarkan hasil wawancara awal dengan pekaseh, dapat diketahui pula bahwa pada tahun 2010 Subak Uma Lambing telah dipilih oleh Dinas Pertanian Kabupaten Badung sebagai subak percontohan dalam hal pengembangan agrowisata, namun dalam prakteknya rencana pengembangan agrowisata tersebut belum mendapatkan tanggapan serius dari desa dinas setempat. Padahal Subak Uma Lambing sebenarnya sangat cocok untuk dikembangkan sebagai kawasan agrowisata. Subak Uma Lambing merupakan salah satu subak di Kabupaten Badung yang berhasil mempertahankan predikat ketahanan pangan sejak tahun 2009. Berdasarkan letaknya, subak ini berada pada lokasi yang tergolong strategis. Terdapat pula beberapa prasarana yang mendukung seperti badan jalan usaha
Peraturan Daerah Kabupaten Badung Nomor 26 Tahun 2013 tentang Rencana Tata Ruang Wilayah Kabupaten Badung tahun 2013 - 2033 pasal 5 ayat 5, dinyatakan bahwa strategi pengembangan Wilayah Badung Tengah merupakan kawasan dengan fungsi utama pertanian berkelanjutan, Ibu Kota Kabupaten dan pusat pelayanan umum skala regional. Fungsi kawasan ini menjadikan kawasan Badung Tengah cocok untuk mengembangkan sebuah objek pariwisata dengan memanfaatkan pertaniannya.

Perkembangan pariwisata dapat memberikan dampak positif dan dampak negatif. Alih fungsi lahan merupakan salah satu dampak negatif pariwisata yang mempengaruhi keberadaan lahan pertanian. Pencegahan alih fungsi lahan pada Kawasan Badung Tengah diatur dalam Peraturan Daerah Kabupaten Badung Nomor 26 Tahun 2013 tentang Rencana Tata Ruang Wilayah Kabupaten Badung tahun 2013 - 2033 pasal 5 ayat 6 huruf a. Pasal tersebut membahas mengenai pengembangan kawasan Badung Tengah sebagai Kawasan Lahan Pertanian Pangan Berkelanjutan dan mengendalikan alih fungsi lahan pertanian beririgasi dalam rangka ketahanan pangan, pelestarian lingkungan dan pelestarian budaya.

Subak merupakan asset daerah yang menawarkan keindahan petakan sawah, kegiatan petani, serta keunikan ritual yang menjadi daya tarik tersendiri bagi wisatawan. Hal ini merupakan peluang yang dapat dimanfaatkan untuk mensinergikan sektor pariwisata dan sektor pertanian dengan mengembangkannya sebagai kawasan agrowisata.

Agrowisata merupakan serangkaian kegiatan wisata tani yang telah dimanfaatkan sebagai jogging track oleh masyarakat sekitar. Adanya kolam ikan yang digunakan untuk budidaya serta kolam pancing. Terdapat kelompok pengembangan ekonomi produksi dengan mengolah hasil pertanian, selain itu subak juga dikelola dalam lingkungan masyarakat yang masih kental dengan adat serta tradisi yang didasari oleh ajaran Agama Hindu.

Meskipun masih terdapat beberapa aspek yang perlu diperbaiki, namun keunggulan-keunggulan tersebut menunjukkan bahwa Subak Uma Lambing sebenarnya sudah siap untuk dikembangkan sebagai kawasan agrowisata. Upaya pengembangan agrowisata juga harus memperhatikan hubungan harmonis dengan Tuhan, sesama dan lingkungan yang berlandaskan konsep Tri Hita Karana agar kegiatan agrowisata dalam berjalan dengan baik. Dalam upaya pengembangan agrowisata tersebut masih perlu dilakukan analisis mengenai potensi serta bentuk pengembangan agrowisata yang tepat. Selanjutnya perlu dilakukan pula analisis mengenai kesesuaian antara keadaan ideal dan keadaan aktual agar dapat diketahui kesesuaian keadaan subak saat ini dengan harapan keadaan subak yang dapat melancarkan terwujudnya agrowisata. Berdasarkan hal tersebut, maka perlu dilakukan analisis mendalam mengenai pengembangan agrowisata berlandaskan konsep Tri Hita Karana di Subak Uma Lambing, Kecamatan Abiansemal, 
Kabupaten Badung.

\section{Rumusan Masalah}

Berdasarkan uraian latarbelakang di atas, maka dapat dirumuskan sebagai berikut.

1. Potensi apa saja yang dimiliki oleh Subak Uma Lambing terkait dengan pengembangan agrowisata berlandaskan konsep Tri Hita Karana?

2. Bagaimanakah bentuk pengembangan agrowisata berlandaskan konsep Tri Hita Karana?

3. Bagaimanakah kesesuaian keadaan ideal dan keadaan aktual di Subak Uma Lambing terkait dengan pengembangan agrowisata berlandaskan konsep Tri Hita Karana?

\section{Tujuan Penelitian}

Adapun tujuan dari penelitian ini adalah sebagai berikut.

1. Untuk menganalisis potensi yang dimiliki oleh Subak Uma Lambing terkait dengan pengembangan agrowisata berlandaskan konsep Tri Hita Karana.

2. Untuk menganalisis bentuk pengembangan agrowisata berlandaskan konsep Tri Hita Karana.

3. Untuk menganalisis mengenai kesesuaian antara keadaan ideal dan keadaan aktual di Subak Uma Lambing terkait dengan pengembangan agrowisata berlandaskan konsep Tri Hita Karana.

\section{TINJAUAN PUSTAKA}

\section{Agrowisata}

Agrowisata merupakan rangkaian kegiatan wisata yang memanfaatkan potensi pertanian sebagai obyek wisata, baik berupa pemandangan alam kawasan pertanian, keunikan dan keanekaragaman dari aktivitas produksi dan teknologi pertanian serta budaya dari masyarakat petaninya. Menurut Betrianis (1996), pengembangan agrowisata merupakan pengembangan model pariwisata yang terpadu antara pengembangan masyarakat desa, alam terbuka, pemukiman desa, budaya, kegiatan pertanian serta sarana pendukung wisata seperti transportasi, akomodasi dan komunikasi.

\section{Subak}

Berdasarkan Perda Provinsi Bali No. 9 tahun 2012, subak merupakan organisasi tradisional di bidang tata guna air dan atau tata tanaman di tingkat usaha tani pada masyarakat adat Bali yang bersifat sosioagraris, religius, dan ekonomis yang secara historis terus tumbuh dan berkembang. Faktor ekonomi memberikan pengaruh terhadap perubahan yang terjadi pada lembaga subak, sehingga perlu dilakukan antisipasi dengan melakukan pendekatan-pendekatan ekonomi agar dapat melestarikan sistem subak di Bali. Sutawan, et al (2005) dalam Sedana (2013) menyebutkan bahwa, tantangan subak ke depan adalah terwujudnya kelembagaan subak dengan kearifan lokalnya mampu menjadi organisasi yang bersifat sosio- agraris-religius yang dapat beradaptasi dengan tuntutan ekonomis anggotanya seiring dengan program-program pembangunan pertanian dan perdesaan.
Orientasi ekonomis pada organisasi pengelola irigasi ini telah banyak digagas terutama di dalam menghadapi era kesejagatan sehingga para petani anggota subak dapat meningkatkan pendapatannya dan sekaligus mampu mengantisipasi terjadinya penyusutan lahan sawah yang tidak terkendali.

\section{Tri Hita Karana}

Tri Hita Karana merupakan sebuah konsep atau filosofi masyarakat Hindu, menurut Arif (1999), dalam Windia dan Dewi (2011), disebutkan bahwa konsep Tri Hita Karana merupakan konsep yang universal yang pada hakikatnya dianut pula oleh masyarakat lain meskipun mereka tidak beragama Hindu. Menurut Sutjipta (2010), filosofi Tri Hita Karana merupakan filosofi yang paling mendalam dari kehidupan komunal masyarakat Bali, dengan demikian Tri Hita Karana sangat perlu dihayati dan dikembangkan.

\section{Kerangka Berpikir}

Pada dasarnya sistem subak sepenuhnya berwatak sosiokultural, berkembang dan mengalami perubahan sesuai dengan perkembangan masyarakat di sekitarnya. Namun seiring dengan perkembangan jaman, tantangan kedepan yang akan dihadapi oleh kelembagaan subak yaitu harus dapat beradaptasi dengan tuntutan ekonomis anggotanya. Dewasa ini sistem subak sudah mulai dikembangkan menjadi suatu usaha yang berwawasan agribisnis, agar mampu diandalkan sebagai penyedia pangan, penyedia kesempatan kerja, penyedia pendapatan, mendorong pertumbuhan ekonomi dan menghasilkan devisa, sehingga perekonomian Bali akan bertumpu pada sektor yang lebih beragam. Untuk mencapai usaha agribisnis yang dapat diandalkan maka sektor pertanian perlu dikemas sehingga memiliki daya tarik. Perkembangan sektor pariwisata di Bali dapat dimanfaatkan sebagai acuan untuk membentuk usaha berwawasan agribisnis, salah satunya dengan mengembangkan agrowisata. Sektor pertanian di Bali dikelola sepenuhnya oleh sistem subak, sehingga pengembangan agrowisata di Bali tidak dapat dilepaskan dari keberadaan sistem subak. Subak merupakan sistem irigasi yang berlandaskan konsep Tri Hita Karana, sehingga pengembangan agrowisata di Bali juga harus dilandasi oleh konsep tersebut.

\section{Konsep Penelitian}

Subak Uma Lambing merupakan salah satu subak yang berada di Kabupaten Badung, yang merupakan pusat pengembangan pariwisata di Provinsi Bali. Untuk mengendalikan dampak negatif dari perkembangan pariwisata terhadap kawasan subak khususnya pada Subak Uma Lambing, maka salah satu alternatif yang dapat dilakukan yaitu dengan mengembangkan agrowisata. Subak merupakan sistem irigasi yang berlandaskan konsep Tri Hita Karana, maka pengembangan agrowisata juga harus mengimplementasikan konsep Tri Hita Karana. Subak pada dasarnya merupakan sebuah sistem teknologi dan merupakan sistem kebudayaan. Pengembangan agrowisata dapat dilakukan dengan menghubungkan semua subsistem pada kedua sistem tersebut 
menggunakan matriks Tri Hita Karana. Sebelum melakukan pengembangan agrowisata, terlebih dahulu dilakukan penggalian informasi mengenai potensi yang ada. Selanjutnya dilakukan penetuan bentuk pengembangan agrowisata yang melibatkan kesepakatan anggota subak, masyarakat sekitar serta pemerintah setempat. Berdasarkan hal tersebut maka dapat diketahui bagaimana pengembangan agrowisata pada Subak Uma Lambing jika dilandaskan pada Konsep Tri Hita Karana.

\section{METODE PENELITIAN}

Penelitian ini menggunakan pendekatan kualitatif, yang dilakukan di Subak Uma Lambing yang berlokasi di Kecamatan Abiansemal, Kabupaten Badung. Jenis data yang digunakan adalah data kualitatif dan kuantitatif dengan sumber data berupa data primer dan data sekunder. Dalam penelitian ini, populasi yang digunakan adalah keseluruhan dari jumlah anggota Subak Uma Lambing yang terdiri atas 296 orang, dengan responden yang digunakan berjumlah 45 orang. Selain itu digunakan pula informan kunci yaitu Pekaseh Subak Uma Lambing, Dinas Pariwisata Kabupaten Badung, serta pelaku pariwisata. Variabel yang digunakan dalam penelitian ini yaitu potensi agrowisata, bentuk pengembangan agrowisata, dan kesesuaian keadaan ideal dengan keadaan aktual.

\section{Analisis Data}

Data pada penelitian ini dianalisis dengan menggunakan metode analisis deskriptif kualitatif. Potensi agrowisata dianalisis dengan melakukan observasi dan wawancara mendalam, bentuk pengembangan agrowisata dianalisi dengan wawancara mendalam. Kesesuaian keadaan ideal dan aktual dianalisis menggunakan matriks hubungan antara semua subsistem dari sistem teknologi dan semua subsistem dari sistem kebudayaan. Tanggapan untuk penilaian keadaan aktual dan keadaan ideal menggunakan keterangan skor. Skoring yang diberikan pada tiap-tiap hubungan subsistem selanjutnya dijumlahkan untuk mendapatkan total nilai. Setelah total nilai diperoleh, selanjutnya total nilai dibagi dengan jumlah pernyataan pada subsistem tersebut maka diperoleh nilai rata-rata. Adapun penentuan total nilai dapat dirumuskan sebagai berikut.

$$
\mathrm{NR}=\mathrm{TN} / \mathrm{JP}
$$

Setelah diketahui rata-rata dari total skor seluruh jawaban responden, selanjutnya perlu diketahui interval kelasnya. Interval kelas ini digunakan untuk menentukan kategori dari setiap ratarata. Menentukan interval kelas dapat dirumuskan sebagai berikut.

$$
\mathrm{I}=\mathrm{Jarak} / \text { jumlah kelas }
$$

Tabel 1. Kategori Tingkat Penerapan THK pada Subak Uma Lambing Berdasarkan Pencapaian Skor

\begin{tabular}{ccl}
\hline No & Pencapaian skor & \multicolumn{1}{c}{ Tingkat penerapan THK } \\
\hline 1 & $1-1,8$ & Sangat Tidak Sesuai \\
2 & $>1,8-2,6$ & Tidak Sesuai \\
3 & $>2,6-3,4$ & Cukup Sesuai \\
4 & $>3,4-4,2$ & Sesuai \\
5 & $>4,2-5$ & Sangat Sesuai \\
\hline
\end{tabular}

\section{HASIL DAN PEMBAHASAN}

\section{Usia responden}

Menurut pendapat Mantra (2004), secara ekonomi usia produktif dibagi menjadi tiga klasifikasi, yaitu kelompok usia 0 - 14 yang merupakan usia belum produktif, kelompok umur 15 - 64 tahun merupakan kelompok usia produktif, serta kelompok umur diatas 64 yang merupakan kelompok usia yang tidak lagi produktif.

Tabel 2. Karakteristik Responden Menurut Kelompok Usia

\begin{tabular}{cccc}
\hline No & $\begin{array}{c}\text { Kelompok } \\
\text { usia (tahun) }\end{array}$ & \multicolumn{2}{c}{ Jumlah responden } \\
\cline { 3 - 4 } & & Orang & Persentase \\
\hline 1 & $0-14$ & 0 & 0 \\
2 & $15-64$ & 32 & 71,11 \\
3 & $>64$ & 13 & 28,89 \\
\hline
\end{tabular}

Sumber: data primer (2019)

Pada Tabel 2 ditunjukkan bahwa, sebagian besar responden termasuk dalam kelompok usia 15 sampai dengan 64 tahun sejumlah 31 orang $(71,11 \%)$, dimana kelompok umur ini merupakan kelompok umur produktif.

\section{Pendidikan responden}

Tabel 3 menunjukkan bahwa sebagian besar responden memiliki tingkat pendidikan SMA dengan jumlah 19 orang $(42,22 \%)$. Selanjutnya 13 orang $(28,90 \%)$ lainnya, hanya mengenyam pendidikan hingga SD. Responden yang memiliki tingkat pendidikan akhir SMP hanya sejumlah 11 orang $(24,44 \%)$. Sedangkan dua responden lainnya tidak pernah mengenyam pendidikan.

Tabel 3. Karakteristik Responden Menurut Tingkat Pendidikan

\begin{tabular}{llcc}
\hline No & \multicolumn{1}{c}{$\begin{array}{c}\text { Tingkat } \\
\text { Pendidikan }\end{array}$} & \multicolumn{2}{c}{$\begin{array}{c}\text { Jumlah } \\
\text { Responden }\end{array}$} \\
\cline { 3 - 4 } & & Orang & Persentase \\
\hline 1 & SMA & 19 & 42,22 \\
2 & SMP & 11 & 24,44 \\
3 & SD & 13 & 28,90 \\
4 & Tidak sekolah & 2 & 4,44 \\
\hline
\end{tabular}

Sumber: data primer (2019)

\section{Status penguasaan lahan}

Secara keseluruhan, luas penguasaan lahan sawah seluruh responden sejumlah 1.925 are. Diketahui bahwa penguasaan lahan responden dengan status lahan sawah yang dimiliki oleh responden pemilik penggarap adalah seluas $1.112(57,77 \%)$, sedangkan luas lahan yang dimiliki responden dengan menggarap adalah seluas 813 are $(42,23 \%)$. Selanjutnya pada luas lahan tegalan yang dimiliki responden pemilik penggarap adalah sejumlah 343 are $(100 \%)$, sementara petani penggarap tidak memiliki tegalan karena hanya menggarap lahan sawah saja. 


\section{Potensi Subak Uma Lambing Terkait Pengembangan Agrowisata Berlandaskan Konsep Tri Hita Karana}

Dalam upaya pengembangan agrowisata pada Subak Uma Lambing, perlu dilakukan penggalian maupun pengembangan potensi pariwisata agar dapat menjadi daya tarik bagi wisatawan. Pengembangan potensi ini tentu perlu dilakukan dengan mengimplementasikan konsep Tri Hita Karana, sehingga hubungan harmonis dengan Tuhan, manusia dan lingkungan tetap terjaga. Pada penelitian ini, potensi agrowisata di Subak Uma Lambing diukur menggunakan tiga indikator yang meliputi daya tarik wisata, sarana dan prasarana, serta aksesibilitas.

\section{Daya Tarik Wisata}

Daya tarik wisata merupakan segala sesuatu yang memiliki keunikan, nilai dan kemudahan berupa keanekaragaman alam, budaya dan hasil buatan manusia yang menjadi kunjungan wisatawan (UU No 10 Tahun 2009). Daya tarik wisata berupa daya tarik alam ciptaan Tuhan Yang Maha Esa, daya tarik karya manusia, maupun daya tarik wisata minat khusus. Tanpa adanya daya tarik di suatu daerah atau tempat tertentu kepariwisataan sulit untuk dikembangkan (Yoeti, 2002 dalam Kirana, 2016).

Berdasarkan pembahasan mengenai daya tarik wisata pada Subak Uma Lambing, dapat diketahui bahwa seluruh parameter berpotensi untuk dikembangkan. Subak Uma Lambing memiliki keindahan alam berupa hamparan sawah dan bunga, memiliki letak yang strategis, komoditas pertanian yang beragam, terdapat ternak sapi dan ikan, terdapat aktivitas ritual yang dilaksanakan, memiliki berbagai budaya daerah yang dapat ditawarkan, serta terdapat makanan olahan hasil pertanian Subak Uma Lambing. Namun, pada keindahan alam kebersihan saluran irigasi perlu diperhatikan kembali agar tetap dapat menjaga kenyamanan pengunjung. Berdasarkan hal tersebut, maka dapat disimpulkan bahwa potensi daya tarik wisata pada Subak Uma Lambing terdiri atas keindahan alam, komoditas pertanian, jenis ternak, aktivitas ritual, budaya, serta makanan olahan dari hasil pertanian.

\section{Sarana dan Prasarana}

Dari pembahasan mengenai sarana dan prasarana di atas, dapat diketahui bahwa sarana yang dapat menjadi potensi yaitu berbagai jenis transportasi yang dapat digunakan menuju kawasan subak serta aliran listrik dan lampu penerangan pada kawasan subak. Sedangkan prasarana yang berpotensi yaitu keberadaan jalan raya dan jalan usaha tani pada subak, lahan yang dapat digunakan sebagai lahan parkir, fasilitas kesehatan, warung krama yang dapat digunakan sebagai kios makanan dan minuman, sebagian gedung koperasi yang dapat dimanfaatkan sebagai toko cinderamata serta rumah krama terdekat yang dapat dimanfaatkan sebagai penginapan.

\begin{abstract}
Aksesbilitas
Berdasarkan pembahasan mengenai aksesbilitas, dapat diketahui bahwa Subak Uma Lambing memiliki potensi dilihat dari aksesbilitasnya. Jarak tempuh yang dekat dari pusat kota dan lokasi wisata lainnya dapat menjadi daya tarik pengunjung untuk melakukan wisata pada Agrowisata Subak Uma Lambing. Setelah melakukan wisata di Agrowisata Subak Uma Lambing, pengunjung dapat melanjutkan wisatanya pada beberapa lokasi wisata terdekat.

\section{Bentuk Pengembangan Agrowisata Berlandaskan} Konsep Tri Hita Karana di Subak Uma Lambing
\end{abstract}

Menurut pendapat Rai (2015), bentuk pengembangan agrowisata dapat diarahkan dalam bentuk ruangan tertutup (seperti museum), ruangan terbuka (taman atau lansekap) atau kombinasi antara keduanya. Berdasarkan pendapat tersebut maka bentuk pengembangan agrowisata pada Subak Uma Lambing akan dilaksanakan dalam bentuk ruangan terbuka. Karena kegiatan agrowisata langsung dilakukan di kawasan Subak Uma Lambing.

Menurut pendapat Koentjaraningrat (1993), dalam Windia dan Dewi (2011), segala hal yang berkaitan dengan budaya/kebudayaan sebagai suatu sistem, maka pembahasan harus meliputi tiga aspek yaitu konsep/pola pikir, subsistem sosial, dan subsistem artefak/kebendaan. Dalam kaitannya dengan konsep Tri Hita Karana, dapat disebutkan bahwa aspek pola pikir analog dengan parhyangan, aspek sosial analog dengan pawongan, dan aspek artefak analog dengan palemahan. Berdasarkan kedua pendapat tersebut diatas, maka segala kegiatan yang termasuk dalam sektor pertanian termasuk pula rancangan bentuk pengembangan agrowisata pada Subak Uma Lambing dapat dikaji dengan menggunakan pendekatan sistem kebudayaan, yaitu aspek pola pikir, aspek sosial, dan aspek artefak.

\section{Aspek pola pikir}

Berdasarkan aspek pola pikir pada krama subak, kenyataan yang dapat dilihat pada lapangan yaitu, krama subak telah menyadari potensi yang terlihat pada lingkungan subak. Namun masih terdapat beberapa krama yang tidak yakin akan terwujudnya agrowisata sehingga tidak berniat serius untuk menanggapi rencana tersebut. Hal ini menunjukkan bahwa masih perlu dilakukannya pendekatan untuk membangun keinginan yang sama pada seluruh krama untuk merealisasikan pengembangan agrowisata. Tahap selanjutnya yaitu membentuk kesepakatan dengan pemerintah dan komponen pariwisata. Kesepakatan ini nantinya akan memberikan kemudahan untuk mempromosikan lokasi agrowisata.

Berdasarkan pembahasan di atas, dapat disimpulkan bahwa pada tahap dasar penentuan bentuk pengembangan agrowisata, pada aspek pola pikir dapat dilakukan dengan cara membangun kesadaran krama akan keberadaan potensi, membangun keinginan krama untuk mengembangkan potensi. Setelah pola pikir krama 
terbentuk, selanjutnya dilakukan kesepakatan dengan pemerintah setempat dan komponen pariwisata untuk mengembangkan agrowisata.

\section{Aspek sosial}

Berdasarkan pembahasan aspek sosial, dapat disimpulkan bahwa pada tahap dasar penentuan bentuk pengembangan agrowisata, pada aspek sosial dapat dilakukan dengan cara membangun kesepakatan krama untuk bersedia mengorbankan lahan, dan kesepakatan meningkatkan pengetahuan dan keterampilan. Setelah kesepakatan terbentuk maka dapat dilanjutkan dengan mempersiapkan paket agrowisata dan biayanya, menyusun awig-awig pengunjung dan membentuk struktur pengelola. Dilanjutkan dengan membuat kesepakatan dalam pembagian porsi pendapatan, dan menjalin kerjasama dengan pemerintah setempat untuk mendapat pendampingan serta melaksanakan study banding pada agrowisata lainnya agar dapat menjaga keberlanjutan agrowisata.

\section{Aspek artefak}

Pada aspek artefak ini, Subak Uma Lambing masih perlu melengkapi sarana dan prasarana yang diperlukan. Selain itu dilakukan pula persiapan keperluan dari agrowisata seperti peta lokasi pelaksanaan paket wisata, mempersiapkan krama untuk membuat cinderamata serta mempersiapkan rumah krama sebagai penginapan dengan terlebih dahulu melakukan kesepakatan. Beberapa hal ini diperlukan untuk dapat menumbuhkan rasa nyaman bagi pengunjung dan membuat mereka ingin melakukan kunjungan kembali.

Berdasarkan pembahasan di atas, dapat disimpulkan bahwa pada tahap dasar penentuan bentuk pengembangan agrowisata, pada aspek artefak dapat dilakukan dengan cara merealisasikan kelengkapan sarana dan prasarana, mempersiapkan rumah penduduk sebagai penginapan, membuat sketsa atau peta paket wisata, serta pembuatan cinderamata oleh krama subak. Setelah melakukan tahap dasar pengembangan agrowisata melalui kesepakatan pada aspek pola pikir, sosial dan artefak, maka bentuk agrowisata yang dapat dikembangkan harus mempertimbangkan kesesuaiannya dengan kondisi lingkungan subak. Adapun alternative bentuk pengembangan agrowisata yang dapat dilakukan yaitu tracking, jogging, cycling, metekap, nandur, manyi, memberi makan sapi, memberi makan ikan, memancing ikan, wisata petik buah dan sayuran, mempelajari alat musik rindik, menyaksikan aktivitas ritual, menikmati kuliner khas Bali, mejejahitan, ngulat capil, hiburan Tari Bali serta menginap di rumah krama subak.

Kesesuaian Keadaan Ideal dan Aktual di Subak Uma Lambing Terkait dengan Pengembangan Agrowisata Berlandaskan Konsep Tri Hita Karana

Pengembangan agrowisata berlandaskan konsep Tri Hita Krana di Subak Uma Lambing dapat dibuatkan matriks hubungan antara semua sub sistem dari sistem teknologi dengan semua sub sistem dari sistem kebudayaan.
Responden akan memberikan tanggapan berupa skoring baik untuk keadaan ideal dan keadaan aktual. Setelah diketahui perbandingan skoring antara keadaan ideal dan aktual pada masing-masing subsistem, selanjutnya dilakukan analisis secara deskriptif terhadap perbandingan skoring tersebut.Untuk selengkapnya dapat dilihat pada Tabel 5.

Tabel 5. Matriks Hubungan antara Sub Sistem dari Sistem Teknologi dan Sub Sistem Kebudayaan dalam Keadaan Ideal dan Aktual

\begin{tabular}{|c|c|c|c|c|c|c|}
\hline \multirow{3}{*}{$\begin{array}{c}\text { Sis tem } \\
\text { tekno } \\
\text { logi }\end{array}$} & \multicolumn{6}{|c|}{ Sistem kebudayaan } \\
\hline & \multicolumn{2}{|c|}{ Pola pikir } & \multicolumn{2}{|c|}{ Sosial } & \multicolumn{2}{|c|}{ Artefak } \\
\hline & $\mathrm{I}$ & $\mathrm{A}$ & $\mathrm{I}$ & $\mathrm{A}$ & $\mathrm{I}$ & $\mathrm{A}$ \\
\hline $\begin{array}{l}\text { Soft } \\
\text { ware }\end{array}$ & 0 & 0 & 4,9 & 4,9 & 4,8 & 3,7 \\
\hline $\begin{array}{l}\text { Hard } \\
\text { ware }\end{array}$ & 4,8 & 4 & 4,8 & 4 & 0 & 0 \\
\hline $\begin{array}{l}\text { Organo } \\
\text { ware }\end{array}$ & 4,9 & 4,9 & 4,8 & 2,7 & 4,9 & 3,5 \\
\hline $\begin{array}{l}\text { Human } \\
\text { ware }\end{array}$ & 4,9 & 4,9 & 0 & 0 & 4,8 & 4 \\
\hline $\begin{array}{l}\text { Info } \\
\text { ware }\end{array}$ & 4,7 & 4,1 & 4,9 & 4,4 & 4,9 & 4,6 \\
\hline
\end{tabular}

Sumber: data primer (diolah, 2019)

\section{Simpulan dan Saran}

\section{Simpulan}

Berdasarkan hasil analisis dan pembahasan yang telah dilakukan, maka diperoleh kesimpul sebagai berikut: subak Uma Lambing memiliki potensi pada daya tarik wisata, sarana dan prasarana serta aksesbilitas yang terdiri atas keindahan alam, komoditas pertanian, jenis ternak, aktivitas ritual, budaya, dan makanan olahan dari hasil pertanian; agrowisata pada subak ini dikembangkan dalam bentuk agrowisata ruangan terbuka dengan belandaskan konsep Tri Hita Karana dalam alternatif bentuk pengembangan tracking, jogging, cycling, metekap, nandur, manyi, memberi makan sapi, memberi makan ikan, memancing ikan, wisata petik buah dan sayuran, mempelajari alat musik rindik, menyaksikan aktivitas ritual, menikmati kuliner khas Bali, mejejahitan, ngulat capil, hiburan Tari Bali, serta menginap di rumah krama subak; dalam penerapan konsep Tri Hita Karana, secara umum mendekati keadaan ideal.

\section{Saran}

Berdasarkan kesimpulan yang telah dijabarkan di atas, maka dapat disarankan hal-hal sebagai berikut: daya tarik wisata pada keindahan alam terkait kebersihan saluran irigasi perlu diperhatikan kembali, seperti kondisi prasarana jalan usaha tani perlu diperbaiki, begitupula pada sarana dan prasarana yang belum tersedia perlu dilengkapi agar dapat memenuhi kriteria sebagai suatu lokasi wisata; untuk dapat merealisasikan bentuk pengembangan agrowisata, maka perlu adanya kesepakatan pada krama untuk mengembangkan potensi serta kerjasama dengan pemerintah setempat dan biro 
pariwisata, serta perlu dilengkapinya sarana dan prasarana yang diperlukan dalam pengembangan agrowisata; dan perlu dilakukannya kerjasama antara lembaga subak dan krama dalam pengelolaan kelompok usaha produksi hasil pertanian, pelaksanaan pembinaan krama subak perlu dilakukan tanpa menunggu tawaran dari pihak luar, pelaksanaan study banding agar penerapan hubungan sub sistem dapat mencapai kategori sesuai.

\section{Daftar Pustaka}

Betrianis. 1996. "Kajian Strategis Pengembangan Kawasan Agrowisata di Kantor Sukabumi" (tesis). Bogor: Institut Pertanian Bogor.

Kirana Pratiwi, Luh Putu. 2016. "Pariwisata Kerakyatan (Community Based Tourism) dan Pengaruhnya pada Kesejahteraan Petani di Desa Budaya Kertalangu Kota Denpasar" (tesis). Denpasar: Universitas Udayana.

Mantra, I.B. 2004. Demografi Umum. Penerbit Pustaka Pelajar: Yogyakarta.

Perda Provinsi Bali No. 9 tahun 2012 tentang Subak.

Perda Kabupaten Badung No. 26 tahun 2013 tentang Rencana Tata Ruang Wilayah Kabupaten Badung Tahun 2013-2030.

Rai Utama, I Gusti Bagus. 2015. Agrowisata Sebagai Pariwisata Alternatif. Universitas Dhyana Pura Bali.

Sedana, Gede.2013. "Modal Sosial dalam Pengembangan Agribisnis Petani pada Sistem Subak di Bali” (disertasi). Denpasar: Universitas Udayana.

Sutjipta, I Nyoman. 2001. Agrowisata (Diktat) Magister Manajemen Agribisnis Universitas Udayana Bali.

Undang-undang Nomor 10 Tahun 2009 tentang Kepariwisataan.

Windia, W dan Ratna Komala Dewi. 2011. Analisis Bisnis Berlandaskan Tri Hita Karana. Udayana University Press, Kampus Universitas Udayana Denpasar. 